\section{Atelectasias Durante Anestesia: Fisiologia e Tratamento}

(Rev Bras Anestesiol, 2007; 58(1): 73-83)

\section{Prezada Editora,}

Foi com grande interesse que li o artigo ${ }^{1}$ publicado na Revista Brasileira de Anestesiologia. Gostaria de parabenizar os autores pela louvável iniciativa. Preocupado em esclarecer alguns aspectos, me ocorreu fazer algumas comentários:

1) Os autores descrevem no artigo que a diminuição da complacência pulmonar e a piora das trocas gasosas seriam os parâmetros utilizados como critérios de indicação para as manobras de recrutamento alveolar. Não houve descrição no artigo sobre qual o instrumento biomédico, estratégia diagnóstica ou monitor que deveria ser utilizado durante a realização de um procedimento cirúrgico para a realização desse diagnóstico. Existe algum? Qual?

2) Os autores defendem que as manobras de recrutamento devem ser utilizadas sempre que possível; entretanto, não descrevem qual o momento ideal para o seu início. O III Consenso Brasileiro de Ventilação Mecânica recomenda que as manobras sejam executadas logo após a instalação da anestesia geral, pois essa estratégia seria uma tentativa de minimizar o momento de maior aparecimento das atelectasias pulmonares durante uma cirurgia, o momento da indução anestésica ${ }^{2}$.

3) Os autores descrevem que os benefícios das manobras de recrutamento vão além da reversão das atelectasias, parecendo fazer uma clara menção de que os benefícios são estendidos durante o período pós-operatório. Contudo, parecem faltar ensaios clínicos aleatórios com intervalo de confiança estreito e com adequado tempo de seguimento para respaldar os efeitos das manobras no pós-operatório, uma vez que o III Consenso de Ventilação Mecânica apresenta o grau de recomendação como B ${ }^{2}$. Aproveito ainda a oportunidade para aplaudir o grande esforço dos autores em tentar trazer ao anestesiologista brasileiro um conhecimento que traz diretamente benefícios ao paciente durante a realização de uma anestesia.

Fabiano Timbó Barbosa, TSA

\section{Atelectasis During Anesthesia: Physiology and Treatment}

(Rev Bras Anestesiol, 2008; 58(1):73-83

To the Editor, I read the study ${ }^{1}$ published on Revista Brasileira de Anestesiologia with great interest. I would like to compliment the authors for their commendable initiative. The following comments are done with the intent of clarifying a few aspects:

1) The authors stated that the reduction in pulmonary complacency and the worsening of gas exchange would be the parameters used as indication that alveolar recruiting maneuvers should be instituted. There was no mention for the biomedical device, diagnostic strategy, or monitor that should be used during surgery to make this diagnosis. Are there any? Which should be used?

2) The authors stated that recruiting maneuvers should be used as often as possible; however, they did not mention the ideal moment to institute those maneuvers. The III Consenso Brasileiro de Ventilação Mecânica (III Brazilian Consensus on Mechanical Ventilation) indicates that those maneuvers should be executed immediately after anesthetic induction in an attempt to minimize the moment of surgery that most atelectasis develop, i.e., during anesthetic induction ${ }^{2}$.

3) The authors also stated that the benefits of recruiting maneuvers go beyond reversal of atelectasis, which seemed to indicate that the benefits extend throughout the postoperative period; however, randomized clinical studies with a narrow confidence interval and adequate follow up to confirm the effects of those maneuvers in the postoperative period are needed, since the III Consenso de Ventilação Mecânica deemed it a $B$ recommendation ${ }^{2}$.

I would like to applaud the efforts of the authors for their attempt to bring to Brazilian anesthesiologists a knowledge that benefits the patient during anesthesia.

Fabiano Timbó Barbosa, TSA

\section{REFERÊNCIAS - REFERENCES}

01. Malbouisson LMS, Humberto F, Rodrigues RR, Carmona MJC Auler Jr JOC - Atelectasias durante anestesia: fisiopatologia e tratamento. Rev Bras Anestesiol, 2007; 58: 73-83.

02. Auler Junior JOC, Galas FRBG, Hajjar LA, Franca AS - III Consenso Brasileiro de Ventilação Mecânica: ventilação mecânica no intra-operatório. RBTI, 2007; 19: 393-398. 